\title{
Australian scallops do not recognise the introduced predatory seastar Asterias amurensis
}

\author{
Kate S. Hutson ${ }^{1,2, *}$, D. Jeff $\operatorname{Ross}^{1}{ }^{1}$ Rob W. Day ${ }^{1}$, John J. Ahern ${ }^{1}$ \\ ${ }^{1}$ Department of Zoology, The University of Melbourne, Victoria 3010, Australia \\ ${ }^{2}$ Present address: School of Earth and Environmental Sciences, Darling Building, DP418, The University of Adelaide, \\ South Australia 5005, Australia
}

\begin{abstract}
Escape responses of Australian scallops (Pecten fumatus and Chlamys asperrima) to native and introduced predatory seastars were compared in laboratory and field trials. The native seastar Coscinasterias muricata elicited an almost immediate escape response by scallops in all trials. In contrast, there was a low frequency of escape response exhibited by scallops when held in contact with the introduced seastar Asterias amurensis. These results are consistent with the hypothesis that escape response in invertebrates has evolved relative to predation risk. The absence of predator recognition in marine invertebrates may have serious implications for wild and farmed populations in southern Australia where introduced predators are prevalent.
\end{abstract}

KEY WORDS: Predator recognition · Escape response $\cdot$ Introduced species $\cdot$ Northern Pacific seastar

\section{INTRODUCTION}

Human-mediated introductions in the marine environment are recognised as a major threat to native biodiversity (Carlton 1989, Steneck \& Carlton 2001). The coastal waters of Australia are no exception, with over 100 introduced and cryptogenic species in Port Phillip Bay alone (Hewitt et al. 2004). One of the more conspicuous introduced species in southern Australian waters is the northern Pacific seastar Asterias amurensis, first recorded in the Derwent Estuary in southeast Tasmania in 1986 (Turner 1992, Buttermore et al. 1994). The seastar is thought to have been introduced to Tasmania in ballast water or as a hull-fouling organism on ships from Japan, although the discovery of an adult in the water intake of a vessel indicates that other methods of transfer are possible (Thresher et al. 2000). The seastar was first discovered on mainland Australia in Port Phillip Bay in 1995, where its population has increased to an estimated $75( \pm 15 \mathrm{SE})$ million in 2000
(Parry \& Cohen 2001). Genetic data indicate that A. amurensis in Port Phillip Bay is the result of translocation from Tasmania (Murphy \& Evans 1998).

Introduced predators are likely to have large impacts on native communities (Elton 1958, Lodge 1993, Lafferty \& Kuris 1994). Members of Asteriodea are among the most important predators in marine benthic systems (Menge 1982). Seastars of the genus Asterias are well known predators of bivalves, causing considerable damage to commercial shellfishes such as oysters, mussels, cockles, scallops and other bivalves (Galtsoff \& Loosanoff 1939, Hancock 1958, Hatanaka \& Kosaka 1958, Nojima et al. 1986). In Japan, outbreaks of Asterias amurensis have caused considerable damage to the shellfish industry (Hatanaka \& Kosaka 1958). Recent work in its introduced range has also shown that while $A$. amurensis is a generalist predator able to consume a wide variety of prey, it has clear food preferences for bivalves (including several commercial species) that live on or just below the sediment surface 
(Ross et al. 2002). This is of particular concern to the small but growing number of Australian commercial operations harvesting wild populations of bivalves that live near the sediment surface. Furthermore, losses of commercial scallop spat over a settlement season due to $A$. amurensis predation are reported to be as high as $50 \%$ in Tasmania (S. Crawford pers. comm.).

Many prey species have evolved adaptations to reduce the risk of being eaten (Legault \& Himmelman 1993). Vermeij (1987) described 2 primary antipredator adaptations by bivalve prey to predation: (1) armour and (2) locomotion. Bivalve prey place differential emphasis on these, by either increasing predator handling time, via armour, or reducing predator encounter rate, via avoidance (Seitz et al. 2001). Locomotive escape behaviours have been described for numerous marine invertebrates, including seastarmediated escape responses in bivalve molluscs (Bullock 1953, Feder 1972). The escape response of bivalves when encountering a seastar include jumping and swimming by clapping of the valves of the shell in rapid succession as seen in scallops, or thrusting out the foot and leaping into the water by pushing against the substrate as seen in cockles (Feder 1972).

A number of possible mechanisms may elicit these escape responses (Thomas \& Gruffydd 1971). Scallops, for instance, have non-cephalic image-forming eyes, which can detect shadows and movements at distance, and extensible tentacles on the mantle edge, which have chemo- and mechanoreceptors (Wilkens 1991). In addition, Mackie (1970) and Phillips (1978) demonstrated that prey can detect the steroid glycosides excreted from the tube feet of seastars.

The present study grew out of an aquarium observation in which contact with the introduced seastar Asterias amurensis did not elicit characteristic escape behaviour in the native commercial scallop Pecten fumatus, which is seen when contact occurs with native seastars such as Coscinasterias muricata. This raises the possibility that prey species, in this case scallops, may not recognise the recently introduced seastar A. amurensis as a predator. We expected that predator and prey response would not be independent, and that this would be reflected in a higher frequency of scallop escape responses to native seastars than to introduced seastars.

\section{MATERIALS AND METHODS}

Laboratory trials. The seastars Asterias amurensis and Coscinasterias muricata, and the scallops Pecten fumatus and Chlamys asperrima, were collected by divers in Port Phillip Bay during February 2003 and held in a filtered, closed-circuit aquarium system.
A. amurensis was not common at the location where the experimental scallops were collected. All species were maintained in separate tanks at a constant temperature of $16^{\circ} \mathrm{C}$. The maximum diameter of seastars ranged from 11.5 to $25.0 \mathrm{~cm}$ for $A$. amurensis and from 16.0 to $33.4 \mathrm{~cm}$ for $C$. muricata. The shell length of scallops ranged from 5.0 to $9.3 \mathrm{~cm}$ for $P$. fumatus and from 3.3 to $5.7 \mathrm{~cm}$ for C. asperrima.

Escape behaviour was studied in 601 glass tanks $(30 \mathrm{~cm} \times 60 \mathrm{~cm} \times 36 \mathrm{~cm})$ with a gravel filter to allow aeration of a $5 \mathrm{~cm}$ deep layer of sediment lining the bottom of the tank. The reaction of the scallops to physical contact with the tube feet at the tip of an arm of a seastar was quantified for each predator prey species combination $(\mathrm{n}=15)$. Different individual prey and predators were used in each trial. Each scallop was placed in the aquarium for at least 15 min before trials to allow it to resume normal behaviour. For Pecten fumatus, individuals were placed flush with the sediment surface as this is their natural resting and feeding position. In contrast, Chlamys asperrima were placed on top of the sediment because they attach to surfaces using bysall threads in the natural environment. We attempted to cause a prey response by moving a predator (seastar) into contact with the mantle of a scallop. A prey response was recorded when the mantle of the scallop was touched with seastar tube feet for a maximum of $60 \mathrm{~s}$. Responses were classed as positive or negative. A positive escape response was recorded if the scallop propelled itself away from the seastar, while a negative response was recorded if the scallop did not behave in a way that propelled it away from the seastar. The time taken to respond was recorded.

Field trials. To test whether differences in escape response between the introduced and native seastars observed in the laboratory extended to field conditions, the trials were repeated in situ in April 2003. The size range of predators and prey were within the same limits as those used in laboratory trials. We used SCUBA to run the trials at a depth of $\sim 12 \mathrm{~m}$, directly offshore from Mornington in Port Phillip Bay where Pecten fumatus is abundant. Divers swam between scallops carefully so as to minimise disturbance to the sediment and scallops. A diver then touched the mantle of $P$. fumatus with a seastar's tube feet for a maximum of $60 \mathrm{~s}(\mathrm{n}=24)$. As described for the laboratory trials, different individual prey and predators were used in each trial, and a positive or negative escape response was recorded on underwater data sheets. A waterproof stopwatch was used to determine the time taken to respond.

The data were cast into 2-way contingency tables of the predictor variable (predator species) by the prey response variable (response/no response) for each scallop trial. Expected frequencies were calculated 
assuming the null hypothesis was true and there was no association between variables. Differences between observed and expected frequencies were tested using the chi-square test (Quinn \& Keough 2002).

\section{RESULTS}

Pecten fumatus and Chlamys asperrima displayed similar escape responses, involving initial extension of the tentacles, opening of the valves and enlargement of the inner fold of the velum (or pallial curtain), allowing water to enter the mantle cavity. This was followed by repetitive and rapid shell closure or 'clapping', resulting in jet-like propulsion of water from the mantle and a swimming movement that lifted the scallop into the water column and away from the predator. Alternatively, a 'jump' response was displayed when water jetted out of the mantle caused a change in the rotation of the shell, but did not lift the scallop into the water.

The responses of Pecten fumatus and Chlamys asperrima differed between the native seastar Coscinasterias muricata, and the introduced seastar Asterias amurensis (Table 1). Contact with C. muricata always elicited a swimming escape response in $P$. fumatus in laboratory and field trials, with a mean response time of $4.5 \mathrm{~s}( \pm 0.7 \mathrm{SE})$ and $7.2 \mathrm{~s}( \pm 2.9 \mathrm{SE})$, respectively. $C$. muricata elicited a swimming escape response in Chlamys asperrima in 13 trials and a jump response in 2 trials. The mean response time was $10.9 \mathrm{~s}( \pm 2.9 \mathrm{SE})$.

In contrast, Asterias amurensis elicited a swimming escape response in Pecten fumatus in 4 of the 15 trials in the laboratory, and in 8 of the 24 trials conducted in the field. In the remaining observations, $P$. fumatus showed varying degrees of tentacle extension, opening of the valves, and enlargement of the inner fold of the velum, but did not swim. One $P$. fumatus in the laboratory appeared to jet water towards A. amurensis, but did not move. In the encounters where A. amurensis elicited a swimming escape response, the mean response time was $17.3 \mathrm{~s}( \pm 5.3 \mathrm{SE})$ in the laboratory and $26.1 \mathrm{~s}( \pm 6.5 \mathrm{SE})$ in the field. Chlamys asperrima did not respond to $A$. amurensis; however, this species behaved similarly to $P$. fumatus when touched by the seastar, i.e. tentacle extension, opening of the valves, and enlargement of the velum occurred.

Chi-square values were highly significant $(\mathrm{p}<0.001)$ for both species of scallop tested in the laboratory and for trials conducted in the field. Consequently, the null hypothesis that predator and prey response is independent was rejected.

\section{DISCUSSION}

Escape behaviours are generally assumed to have evolved as a result of predation pressure (Feder 1972, Sih et al. 1988, Duffy \& Hay 2001). An active escape response is usually evoked after recognition of a specific predator (Kohn 1961, Phillips 1976). For example, the North American whelk Buccinum undatum responds strongly to its main asteroid predators in laboratory trials, but not to asteroids that do not naturally attack it, suggesting that bivalves can discriminate between predatory and non-predatory asteroids (Thomas \& Himmelman 1988). In our study, the native seastar Coscinasterias muricata elicited almost immediate escape responses by the scallops, indicating that they are aware of the potential predation threat. In contrast, the low frequency of escape responses to Asterias amurensis suggests that scallops do not recognise the introduced seastar as a predator that should be avoided. According to Vermeij (1994), prey response to predators depends on the frequency of interaction of the species involved. We suggest that scallops do not recognise the recently introduced predator as they have not co-evolved.

Although we are unaware of any other studies that have compared escape responses of invertebrate prey to native and introduced predators, we might expect parallel changes in the intensity of escape responses

Table 1. Frequency and mean escape response time (mean \pm SE) of scallops to native and introduced seastar predators. NR: no response. All results are very highly significant at $p<0.001$

\begin{tabular}{|c|c|c|c|c|c|c|}
\hline \multirow[t]{2}{*}{ Species } & \multirow{2}{*}{$\begin{array}{c}\text { No. of } \\
\text { trials }\end{array}$} & \multicolumn{2}{|c|}{ Coscinasterias muricata } & \multicolumn{2}{|c|}{ Asterias amurensis } & \multirow{2}{*}{$\begin{array}{l}\text { Chi-square } \\
\text { value }\end{array}$} \\
\hline & & $\begin{array}{c}\text { Response } \\
\text { number (\%) }\end{array}$ & $\begin{array}{l}\text { Response } \\
\text { time (s) }\end{array}$ & $\begin{array}{c}\text { Response } \\
\text { number (\%) }\end{array}$ & $\begin{array}{l}\text { Response } \\
\text { time (s) }\end{array}$ & \\
\hline \multicolumn{7}{|l|}{ Lab trials } \\
\hline Pecten fumatus & 15 & $15(100)$ & $4.5( \pm 0.7)$ & $4(27)$ & $17.3( \pm 5.3)$ & 17.37 \\
\hline Chlamys asperrima & 15 & $15(100)$ & $10.9( \pm 2.9)$ & $0(0)$ & NR & 30.0 \\
\hline \multicolumn{7}{|l|}{ Field trials } \\
\hline Pecten fumatus & 24 & $24(100)$ & $7.2( \pm 2.9)$ & $8(33)$ & $26.1( \pm 6.5)$ & 24.0 \\
\hline
\end{tabular}


among locations that vary in predator abundance and activity. This is indicated by Thomas \& Himmelman's (1988) observations of escape responses of the whelk Buccinum undatum to the asteroid predator Leptasterias polaris on the Atlantic coast of Canada. Whelks from the Bay of Fundy, where Leptasterias is absent, did not react to contact with Leptasterias. Given that the population of Asterias in Port Phillip Bay has increased and spread dramatically in recent years, we might expect a concomitant increase in selection pressure on scallops to develop anti-Asterias adaptations. Sih et al. (1988) predict that anti-predator adaptations should develop rapidly when there is predation pressure, and Remy et al. (1998) showed that experience with predators can cause the development of escape responses in B. undatum, providing the first experimental evidence of learned anti-predator behaviour in a mollusc. Sih et al. (1988) suggest that some adaptations have evolved over many generations, whereas others are more plastic and are probably developed or lost over much shorter periods. The recent invasion of A. amurensis in Port Phillip Bay provides an ideal opportunity to examine whether anti-predator adaptations against $A$. amurensis predation can develop in scallops and other prey.

It is relatively easy to quantify and compare escape response frequency and intensity, but the risk of predation (i.e. the probability of mortality from predation over a given time) is more difficult to quantify (Legault \& Himmelman 1993). The low escape response frequencies to Asterias amurensis observed in this study suggest that the risk of predation on scallops is greater for the introduced than the native seastar. Similarly, Barbeau \& Scheibling (1994) found that small scallops experienced higher predation rates by Asterias vulgaris because they had less powerful and less frequent escape responses than larger ones.

In future studies, we plan to evaluate whether the introduced predator presents a high predatory risk. In a preliminary study, we videotaped the success of introduced and native seastar attacks on scallops in the laboratory and the field. Scallops always fled from Coscinasterias muricata but did not respond to Asterias amurensis and were consequently captured and eaten (J. J. Ahern unpubl. data). A known proclivity for surface-dwelling bivalves (Ross et al. 2002, 2003, 2004), and field observations of Asterias feeding on scallops in its native range (Hatanaka \& Kosaka 1958, McLoughlin \& Bax 1993) combined with these preliminary observations are consistent with the hypothesis that Asterias does present a major threat. However, before we can compare the relative risks of predation of the introduced and native seastars, the frequency and success of seastar encounters with scallops needs to be quantified in the field.
Acknowledgements. We thank A. L. O'Brien and P. F. E. Addison from the University of Melbourne and G. D. Parry from the Marine and Freshwater Research Institute for assistance with specimen collections. B. D. Russell from the University of Adelaide kindly read the manuscript.

\section{LITERATURE CITED}

Barbeau MA, Scheibling RE (1994) Behavioural mechanisms of prey size selection by seastars (Asterias vulgaris Verill) and crabs (Cancer irroratus Say) preying on juvenile sea scallops (Placopecten magellanicus (Gmelin)). J Exp Mar Biol Ecol 180:103-135

Bullock TH (1953) Predator recognition and escape responses of some intertidal gastropods in the presence of starfish. Behaviour 5:130-140

Buttermore RE, Turner E, Morrice MG (1994) The introduced northern Pacific seastar Asterias amurensis in Tasmania. Mem Queensl Mus 36:21-25

Carlton JT (1989) Man's role in the changing face of the ocean: biological invasions and implications for conservation of near-shore environments. Conserv Biol 3:265-273

Duffy JE, Hay ME (2001) The ecology and evolution of marine consumer-prey interactions. In: Bertness MD, Gaines SD, Hay ME (eds) Marine community ecology. Sinauer Associates, Sunderland, MA, p 131-157

Elton CS (1958) The ecology of invasions by animals and plants. Methuen, London

Feder HM (1972) Escape responses in marine invertebrates. Sci Am 227:92-100

Galtsoff PS, Loosanoff VL (1939) Natural history and method of controlling the starfish (Asterias forbesi, Desor). Bull Bureau Fish 39:75-132

Hancock DA (1958) Notes on starfish on an Essex oyster bed. J Mar Biol Assoc UK 37:565-589

Hatanaka M, Kosaka M (1958) Biological studies on the population of the starfish, Asterias amurensis, in Sendai Bay. Tohoku J Agr Res 9:159-178

Hewitt CL, Campbell ML, Thresher RE, Martin RB and 15 others (2004) Introduced and cryptogenic species in Port Phillip Bay, Victoria, Australia. Mar Biol 144:183-202

Kohn AJ (1961) Chemoreception in gastropod molluscs. Am Zool 1:291-308

Lafferty KD, Kuris AM (1994) Potential uses for biological control of alien marine species. In: Cottingham D (ed) Nonindigenous estuarine and marine organisms (NEMO). NOAA, US Dept. Commerce, Seattle, WA, p 97-102

Legault C, Himmelman JH (1993) Relation between escape behaviour of benthic marine invertebrates and risk of predation. J Exp Mar Biol Ecol 170:55-74

Lodge DM (1993) Biological invasions: lessons for ecology. Trends Ecol Evol 8:133-137

Mackie AM (1970) Avoidance reactions of marine invertebrates to either steroid glycosides of starfish or synthetic surface-active agents. J Exp Mar Biol Ecol 5:63-69

McLoughlin R, Bax, N (1993) Scientific discussions in Japan and Russia on the northern Pacific seastar. Division of Fisheries, CSIRO, Hobart

Menge BA (1982) Effects of feeding on the environment: Asteroidea. In: Jangoux M, Lawrence JM (eds) Echinoderm nutrition. AA Balkema, Rotterdam, p 521-551

Murphy N, Evans B (1998) Genetic origin of Australian populations of Asterias amurensis. In: Goggin LC (ed) Proceedings of a meeting on the biology and management of the introduced seastar Asterias amurensis in Australian waters. CSIRO Division of Marine Research, Hobart, p 22-25 
Nojima S, Soliman FA, Kondo Y, Kuwano Y, Nasu K, Kitajima C (1986) Some notes of the outbreak of the sea star Asterias amurensis versicolor Sladen, in the Ariake Sea, western Kyshu. Amakusa Mar Biol Lab 8:89-112

Parry GD, Cohen BF (2001) The distribution, abundance and population dynamics of the exotic seastar Asterias amurensis during the first three years of its invasion of Port Phillip Bay. Report No. 33, Marine and Freshwater Research Institute, Queenscliff

Phillips DW (1976) The effect of a species-specific avoidance response to predatory starfish on the intertidal distribution of two gastropods. Oecologia 23:83-94

Phillips DW (1978) Chemical mediation of invertebrate defensive behaviours and the ability to distinguish between foraging and inactive predators. Mar Biol 49:237-243

Quinn GP, Keough MJ (2002) Experimental design and data analysis for biologists. Cambridge University Press, Cambridge

Remy R, Arsenault DJ, Justome B, Himmelman JH (1998) Chemically-mediated predator-recognition learning in a marine gastropod. Ecoscience 5:353-360

Ross DJ, Johnson CR, Hewitt CL (2002) Impact of introduced seastars Asterias amurensis on survivorship of juvenile commercial bivalves Fulvia tenuicostata. Mar Ecol Prog Ser 241:99-112

Ross DJ, Johnson CR, Hewitt CL (2003) Variability in the impact of an introduced predator (Asterias amurensis: Asteroidea) on soft-sediment assemblages. J Exp Mar Biol Ecol 288:257-278

Ross DJ, Johnson CR, Hewitt CL, Ruiz GM (2004) Interaction

Editorial responsibility: Otto Kinne (Editor-in-Chief), Oldendorf/Luhe, Germany and impacts of two introduced species on a soft-sediment marine assemblage in SE Tasmania. Mar Biol 144:747-756

Seitz RD, Lipcius RN, Hines AH, Eggleston DB (2001) Density-dependent predation, habitat variation, and the persistence of marine bivalve prey. Ecology 82:2435-2451

Sih A, Englund G, Wooster D (1988) Emergent impacts of multiple predators on prey. Trends Ecol Evol 13:350-355

Steneck RS, Carlton JT (2001) Human alterations of marine communities - students beware! In: Bertness MD, Gaines $\mathrm{SD}$, Hay ME (eds) Marine community ecology. Sinauer Associates, Sunderland, MA, p 445-468

Thomas GE, Gruffydd LID (1971) The types of escape responses elicited in the scallop Pecten maximus by selected seastar species. Mar Biol 10:87-93

Thomas GE, Himmelman JH (1988) Influence of predation on shell morphology of Buccinum undatum L. on the Atlantic coast of Canada. J Exp Mar Biol Ecol 115:221-236

Thresher RE, Werner M, Hoeg JT, Svane I, Glenner H, Murphy NE, Wittwer C (2000) Developing the options for managing marine pests: specificity trials on the parasitic castrator, Sacculina carcini, against the European crab, Carcinus maenas, and related species. J Exp Mar Biol Ecol 254:37-51

Turner E (1992) A northern Pacific seastar, Asterias amurensis, in Tasmania. Aust Mar Sci Bull 120:18-19

Vermeij GJ (1987) Evolution and escalation: an ecological history of life. Princeton University Press, Princeton, NJ

Wilkens LA (1991) Neurobiology and behaviour of the scallop. In: Shumway SE (ed) Scallops: biology, ecology and aquaculture. Elsevier, Amsterdam, p 429-469

Submitted: August 30, 2004; Accepted: April 21, 2005

Proofs received from author(s): July 29, 2005 